\title{
CУCCIIIb/HO-ГEOГPAक/L//II ВOCกIOKEHHЯ
}

UDC 332.1

DOI: https://doi.org/10.15407/ugz2020.03.036

\section{Leonid Rudenko., Sergiy Lisovskyi, Eugenia Maruniak}

Institute of Geography of the National Academy of Sciences of Ukraine, Kyiv

\section{DILEMMAS OF REGIONAL DEVELOPMENT IN UKRAINE}

The typical problems of regional development are polarization and conflict. Their solution must be provided through specific programs and strategies, and requires the introduction of concepts and knowledge in accordance to the content of the challenges and the stage of social development. Post-Soviet countries, including Ukraine, are still undergoing transformations caused by changes in managerial patterns, consciousness, and a revision of the methodological bases for the implementation of state regional policy. The paper concentrates on the analysis of key features of Soviet territorial planning and scientific research of that time, which have partly led to gaps in relevant policy in modern Ukraine, which, unfortunately, is still poorly harmonized with EU policy. Another aspect of the publication is the identification of regional development disparities. In particular, it includes the effects of geopolitical influences, the excessive concentration of financial, industrial, and human resources in specific centers, the processes of peripheralisation, depopulation, as well as the problems of accessibility and low level of network development. The novelty of the study has been primarily defined due to the comprehensive view on the problems of regional development in Ukraine, both in terms of methodological support and prerequisites for regional policy forming, and in terms of its compliance with current European planning concepts and practices. There are first of all concepts of territorial capital (place-based approach), polycentric and balanced territorial development and territorial cohesion of the functional territories, as well as approaches to forecast and modeling of spatial development. The authors also present the general framework for the conceptualization of spatial development policies in Ukraine, necessary for the successful governance of the country and regions in the context of globalization.

Keywords: spatial development; territorial planning; regional development; geopolitical influences; globalization; polarization.

\section{Леонід Руденко., Сергій Лісовський, Євгенія Маруняк Інститут географії Національної академії наук України, Київ ДИЛЕМИ РЕГІОНАЛЬНОГО РОЗВИТКУ В УКРАЇН}

Типовими проблемами регіонального розвитку є поляризація та конфліктність. Їх вирішення повинно забезпечуватися за допомогою конкретних програм та стратегій і потребує впровадження концепцій та знань відповідно до змісту викликів та стадії соціального розвитку. Країни пострадянського простору, включаючи Україну, все ще переживають трансформації, спричинені зміною управлінських моделей, свідомості та переглядом методологічних засад реалізації державної регіональної політики. У статті проаналізовано ключові особливості радянського територіального планування та наукові дослідження того часу, які частково призвели до прогалин у відповідній політиці сучасної України, яка ще недостатньо гармонізована з політикою Європейського Союзу. Інший аспект дослідження - виявлення відмінностей регіонального розвитку. Зокрема, він включає наслідки геополітичних впливів, надмірну концентрацію фінансових, промислових та людських ресурсів у конкретних центрах, процеси периферійності, депопуляції, а також проблеми доступності та низький рівень розвитку мережі. Новизна дослідження визначається насамперед завдяки всебічному погляду на проблеми регіонального розвитку в Україні, як з точки зору методологічного забезпечення та передумов формування регіональної політики, так і з точки зору ії відповідності сучасним європейським концептам та практикам планування. Це, в першу чергу, концепції територіального капіталу (локалізаційний підхід), поліцентричного та збалансованого територіального розвитку та територіальної згуртованості функціональних територій, а також підходи до прогнозування та моделювання просторового розвитку. Представлено загальну основу для концептуалізації політики просторового розвитку в Україні, необхідну для успішного управління країною та регіонами в контексті глобалізації.

Ключові слова: просторовий розвиток; територіальне планування; регіональний розвиток; геополітичні виливи; глобалізачія; поляризачія.

(c) L. Rudenko, S. Lisovskyi, E. Maruniak, 2020 


\section{Relevance of the researched topic}

Achievement of territorial cohesion is one of the priority tasks for most EU countries today and for Ukraine, which is still undergoing some postSoviet transformational processes, its importance is especially high. On the one hand, it can be explained by the peculiarities of economic development, some trivial and some not so easily discernable issues with depressed conditions in certain types of regions, technological fall back and some negative social phenomena.

On the other hand, it is worth to point the weakness of government policy, lack of modern mechanisms to govern and legislative basis for their implementation. So, while the foundation of regional policy in the EU countries was laid approximately in the middle of the twentieth century, in Ukraine, which inherited the Soviet tradition of power centralization, visible shifts are noticeable only at the beginning of the twenty-first century. The first concept of national regional policy was adopted in 2001 (Presidential Decree, 341/2001). Later, the Regional Development Strategy till the year 2015 (Decree of the Ukraine Cabinet of Ministers No. 1001 of 21 July 2006) was presented, however both this and the following document for the period to the year 2020 (Decree of the Ukraine Cabinet of Ministers of August 6, 2014 No. 385) quite poorly affected the directions and activities in the area of spatial development. A separate block of issues in the area of balanced development and environmental policy also did not achieve the necessary degree of implementation.

In addition, it is worth mentioning the historical and civilizational prerequisites of the Ukrainian state formation, which led not only to shaping certain cultural and religious traditions, but also to a number of conflicts and inter-regional differences.

In general, the negative features of spatial development still remain at both regional and local levels: a prolonged decline in population, increase in socio-economic disparities and pronounced polarization of the economic landscape, out of control urbanization and suburbanization processes, degradation in a significant number of rural settlements and small towns, low level of accessibility and high risks of peripheralization of some territories, insufficient infrastructure, excessive environmental impact and intensifying environmental problems.

Significant positive developments in shaping the Ukraine regional and local development policy undoubtedly have to do with signing the Association
Agreement between Ukraine and the European Union and gradual implementation of its provisions. It was marked by a number of reforms, changes in legislation and active implementation of international projects and practices.

\section{Current state and methodology: changing concepts and gaps in the policy of spatial development planning}

It is quite obvious that after being a part of the USSR for more than 70 years, Ukraine inherited the main patterns of management and planning, some of which are still relevant today, after over 25 years of independence.

It should be noted, however, that the ideals of Marxism and Bolshevism found a rather strange manifestation in the Soviet practice of territorial development. Analyzing the planning in the USSR, the authors [1] point out several fundamental provisions, declared at the early stages of the state formation. It is about "society of unparalleled production and wealth, embodying great technical progress", "equal ability of all to enjoy access to society's resources according to their needs", "nature used for the benefit of man, but in a rational way". In the spatial dimension there also was reference to "gradual abolition of the distinction between a town and country", "rational distribution of industry which facilitates... the complex development of regions and specialization of their economies" and "avoidance of the extreme concentration of population in large cities". Regional policy was also formally aimed at levelling out and self-sufficiency of territorial units.

At the same time, implementation of such goals resulted in excessive centralization of management, no flexible mechanisms for territorial development with coordinated links between sectors, interregional and sectoral disparities, technological fall back and energy inefficiency of many industries, depletion of natural resources and degradation of ecosystem in many regions. The declared regional policy was interpreted quite correctly, "based on the fact of regional discreteness of space, different value of regions by development factors and goals, and, consequently, built differentially" [2], but implemented inconsistently, poorly coordinated with directive approach and finally did not correspond with the declared priorities. The representation of local interests was even weaker. The meaning of location was well understood by the Soviet geographers and economists, while at the same time the potential 
competitive advantages were considered only from the top-to-bottom approach point of view, the expediency of placing production and labor resources and the development of a "socialist economy".

It is also important to point the clear dominance of economic interests over social and environmental, expressed by the "energy production cycles" concepts (based on raw materials and energy links), "territorial industrial complexes" (additional economic effect due to the location of the production sites) by M.Kolosovskyi, as well as research and development on economic zoning (I. Alexandrov, M. Kolosovskyi, M. Baranskyi, K. Voblyi, etc.). At the same time, the issues of society interaction with nature and population distribution were already considered in the works of M. Baranskyi (under the influence of American geography). Later, under the influence of R. Morrill's work "The Spatial Organization of Society" [3], the issues of population settlement planning make their way to the writings of B. Khorev, V. Davidovich, V. Pokshyshevsky, G. Lappo, and the very concept of the "territorial organization of society" becomes fundamental for the Soviets, and, later, for Ukrainian geographers and economists, and is being implemented in the planning activities.

However, in the Soviet planning, in contrast to the European countries and decisions of the CEMAT (Council of Europe Conference of Ministers responsible for Spatial/Regional Planning) conferences, the ideologies of the national economy, industries and economic regions continued to exist up until the time of the USSR collapse.

Thus, after independence, Ukraine faced not only the problems of socio-economic development, but also the formation of institutional environment, methodological and ideological "reboot", introduction of effective approaches in the field of spatial development and planning.

In methodological context, the 1990s were marked by increasing attention to zoning of the Ukraine territory, as well as attempts to conceptualize the definitions of "region" and "regional policy". This enriched the discourse with historical, political and geopolitical, cultural and ethnic dimensions, as well as with somewhat new views on natural preconditions and administrative and territorial structure.

At the same time, the attention should be drawn to such features of the region as: dual role (combination of upper and lower government subsystems); territorial integrity (integrative geosystem); interregional differences in natural, economic, social, environmental and other living conditions of the population; a combination of typicality and uniqueness [4].

One of the best, in our opinion, is to define the state regional policy as the "sphere of the state influence, where spatial development of the country is administered using the legislative, economic, social and technological means to ensure its unity. The essential nature of regional policy is to achieve sustainable development of its individual regions and high competitiveness of the country as a whole" [5].

During the 1990s - 2000s, more than 20 zoning schemes based on various principles were proposed, among which the natural-economic zoning can be distinguished [6].

Unfortunately, at the legislative level, only the economic zoning created the Council for Study of Ukraine Productive Forces at NAS of Ukraine (draft Law of Ukraine "On the Concept of State Regional Economic Policy") was manifested. This trend was followed further.

A significant factor within ineffective solution of the regional development problems was the actual absence of some spatial development policy at the national level. The provisions of the European Spatial Development Perspective, as well as other CEMAT documents, have not been adapted in Ukraine, despite the efforts of some individual authors to convey their content to the professional audience (see, for instance, [7]). Even one of the CEMAT conferences ("Comprehensive Approach to the Balanced Sustainable Spatial Development of the European Continent", 2009) held in Kyiv, did not contribute to this goal. Accordingly, the issues of polycentric development, territorial cohesion, networks and accessibility, approaches to allocation of some specific types of regions, preservation of regional identity have not been realized in territorial development management.

The General Scheme for Planning the Ukrainian Territory (Law of Ukraine N 3059-III, 2002), became some kind of spatial development concept analogue in Ukraine, where the principles of compliance with the final documents of the United Nations Conference on Human Settlements (HABITAT-II) and the corresponding United Nations Economic Commission for Europe and the Council of Europe recommendations are stated. At the same time, both the General Scheme and the territorial planning schemes at the regional and local levels have had 
a pronounced orientation at urban development and, only in recent years, have been the subject of attention from the point of view of sectoral policies. However, the positive is the hierarchical nature and legal binding of these documents.

Highlights, which however were clearly traced in the implementation of the regional policy, should include cross-border cooperation and development of the depressed territories. The momentum for cross-border cooperation development was given by the European Framework Convention on Transborder Cooperation, which Ukraine joined in 1993. Subsequently, it was supported by signing a number of interstate agreements, President of Ukraine Decrees, agreements on the creation of the Euro regions, implementation of international programs, etc. The role of borders and border co-operation in the regional development are also widely discussed in scientific literature, as a rule, in the context of transition of the basic European identification concepts into Ukrainian realities and particularly with regard to the north-eastern borders. Almost complete absence of geopolitical context and elements of security doctrine in these studies should be pointed out, which subsequently manifested in unwillingness to respond to Russian invasion.

The issue of support for "depressed territories" (under marginalization and peripheralization) has become a major point in the 2000 s, both in scientific discourse, primarily in the studies of geographers and economists (see [8-10], and at the legislative level. In 2005, the Law of Ukraine "On Stimulating the Development of Regions" (No. 2850-IV) was adopted, where an attempt was made to identify a depressed territory, the typicality and criteria necessary to classify it within this category. Although the approach used in the Law has a number of shortcomings, and no single approach to assessment of the depressed state and classification of such territories was formed in the scientific circles, the attempt itself to isolate the problem areas and justify the actions on their management was positive.

In contrast to the marginalized state, the possibilities of the growth poles concept or centers of socio-economic activity as the basis for the country and region's spatial framework were also introduced. The main point of this concept and its main features are briefly covered in the monograph "The Problems of Complex Development of Teritory", published back in 1994 [11]. At the same time, the attempts to put this concept into practice remained futile.
As one of the most successful ways to apply international, and in particular European experience in the area of regional development management, should be recognized the provision of strategic planning process. In political prospective, the Decree of the President of Ukraine No. 341/2001 "On The Concept Of The State Regional Policy" was of significant importance, which subsequently caused the emergence of two state regional development strategies - to the years 2015 and 2020. Accordingly, the strategic planning process began at the regional and even at the local levels. The development of many regional strategies, especially the "second wave" (to 2020), were supported by international projects, which made a positive impact on the methodological component (justification of goals, SWOT analysis and search for scenarios). At the same time, the unified approach led to inadequate consideration of some regional specifics and spread of the same goals (for example, development of rural areas). Strategies developed on the basis of "internal resources" are often formal and not given enough consideration, incorrect in terms of terminology and structure of the action aims. The common disadvantage is their dissociation from the spatial planning documents, low integration with ecological component and spatial aspects.

Another important implication was the introduction of the concept of sustainable development and the gradual spread of the principles set out in the Agenda for the 21st century in the area of regional and local development management. In this respect, the contribution of geographical science is perhaps the largest, ranging from the studies of interaction between nature and society to the development of the concept and strategy of sustainable development in Ukraine [12-16]. For almost 30 years, research and discussion in this area have been supporting the strengthening of environmental policy and integration of the Rio convention principles across different sectors.

After all, one of the most recent and obviously successful reforms is the decentralization of public administration, which involves changes in the administrative and territorial structure, creation of united territorial communities with appropriate budgets and powers, and achievement of some compliance with the European NUTS standards.

Thus, the methodology and practice of the modern regional and local development in Ukraine appeared under the influence of the following factors: 
- approaches and concepts of the Soviet period with typical features of centralization and dominance of the "economic expediency";

- scientific and expert community's awareness of studies of foreign regionalists and relevant conceptualization;

- distancing the political and scientific discourses, low intensity of interaction between governmental and research structures;

- the complex and still incomplete process of creation of the national institutional environment;

- partial underestimation of historical prerequisites, as well as geopolitical and geo-economic impacts on formation and implementation of the regional policy;

- ambiguous attempts to apply European and international experience;

- numerous obstacles in of the integrated spatial planning process.

Thus, the purpose of the paper is to analyze the reflection of main concepts and policy gaps at the regional and local levels looking at modern and featured development challenges and responses.

\section{Contradictions and challenges in socio-economic development at the regional level (regions, centers, links)}

Disparities in regional and local development is not a new problem and is recognized in most countries of the world. At the same time, the degree of this disparity, its economic, social and environmental dimensions and, ultimately, the availability of benefits varies and depends on location and links. In addition, the effectiveness of regional policies aimed at overcoming disparities is also different.

For a long time, Ukraine have been defined within coordinates of the East and West, centralization and decentralization, short-term profits and longterm strategies. Such deviations resulted in obvious contrasts in spatial development, crisis phenomena in economy and society, increased degradation of natural ecosystems, and violation of territorial integrity. After the 2014 "reboot", we can talk about some certainty, first shifts and reform in the sectoral policy. But given the magnitude of the problems, their solution will take place in a somewhat distant perspective.

First of all, let us turn to the question which has gained political and geopolitical gravity in the last decade - the contrasting of eastern and western regions. Rejecting S. Huntington's assumption of Ukraine as divided by "the clash of civilizations", it is still worth to look into the regional peculiarities formed under the influence of some known historical events. Western regions form the first pole, annexed to Ukraine in 1939 (Zakarpatska - in 1945), and almost until the collapse of the USSR was viewed by the Soviet authorities as a potential center of nationalism. Staying still almost mono-ethnic they tend to preserve language, traditions, religion as well as have higher migration activity, national and political consciousness, pronounced economic behavior (private initiative and dynamism). No doubt there is influence from neighboring countries, Poland, Romania, Hungary, Slovakia, which in itself can be the subject of a separate study. In this context quite interesting are the results of the "Phantom Borders in Central and Eastern Europe" project [17] (the concept in [18]).

In contrast, the eastern "pole", in its extreme expression, is widespread on the territory of Donetska and Luhanska regions, and to a lesser degree in Kharkivska, Dnipropetrovska, and Zaporizka regions, still feels the reflection of the Soviet era. The share of ethnic Russians there is quite high (at the time of the 2001 census the largest - in Lugansk and Donetsk $-44.8 \%$ and $38.2 \%$, somewhat smaller, 17 $25 \%$ - in the rest of the regions), who were displaced here after the Holodomors of 1932-1933 and 19461947 and after extermination of Ukrainian peasantry. Total industrialization, destruction of the traditional society values, specifics of the lifestyle in numerous mono-industrial settlements led to the formation of a special type of consciousness "Homo Sovietikus". Preference is given to centralization and stability, even under the conditions of low standards of living.

Despite the differences mentioned above, there was a natural process of gradual stereotypes "erosion", caused by internal migration, increasing openness of the Ukrainian economy and society in the conditions of globalization, formation of unified socio-cultural context in the country. Its unfinished state and occupation of Donbass were primarily the result of political speculation and Russian pressure. However, it is hard not to notice the weakness and short-sightedness of the concept and strategies in the national regional policy. Issues of Crimea and Donbass have never been properly addressed in such documents. The vision of a balanced development in the multi-ethnic regions - Odeska, Zakarpatska, Chernivetska regions still remains a weak point as well as another issues of regional policy [19].

In the context of socio-economic development, 


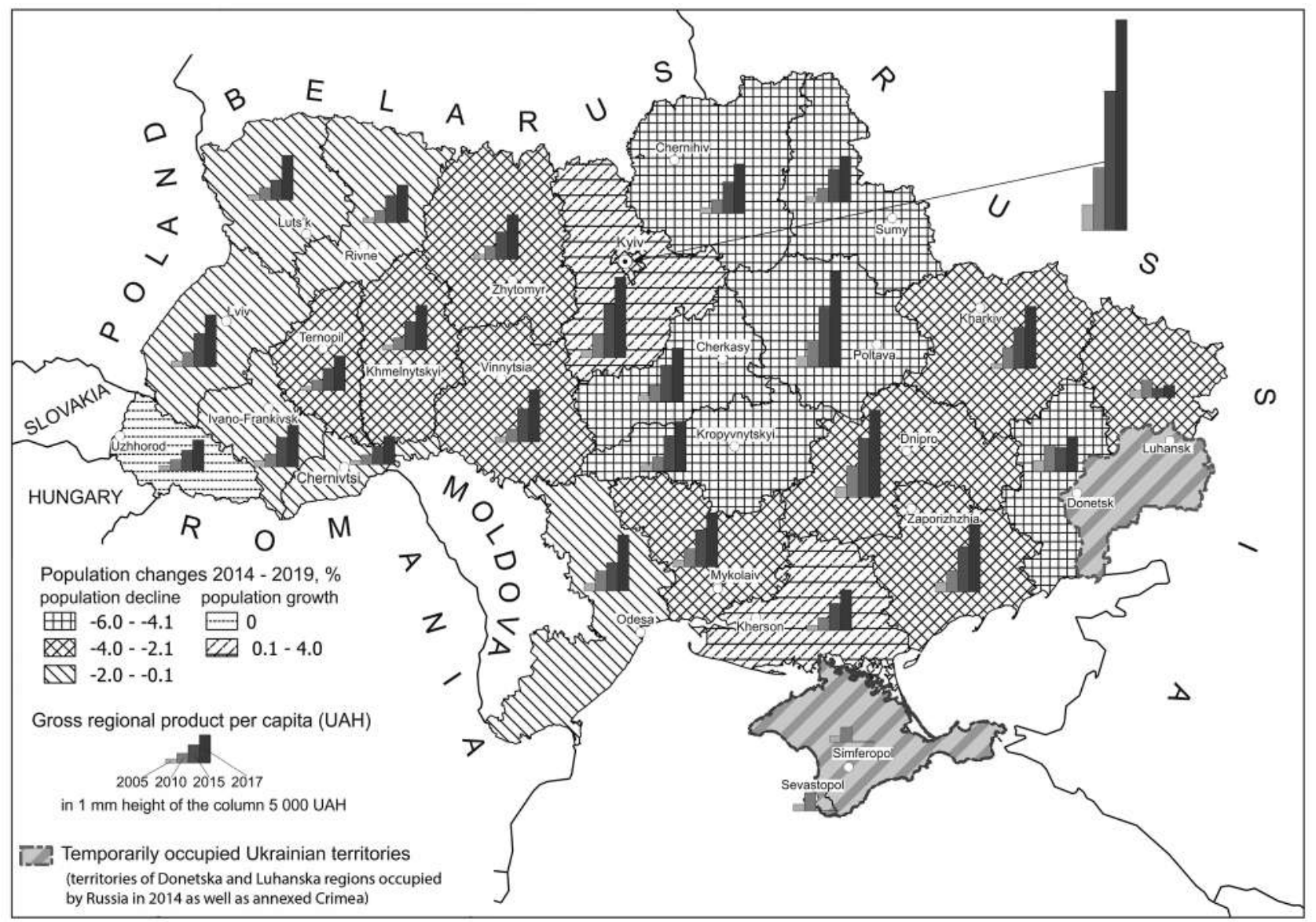

Fig. 1. GRP and population changes in Ukraine. Data source [20]

Population concentration in region (oblast) centers of Ukraine

\begin{tabular}{|c|c|c|}
\hline $40-60 \%$ & $20-30 \%$ & Less then $20 \%$ \\
\hline $\begin{array}{c}\text { Kyivska, Kharkivska, Odeska, } \\
\text { Mykolaivska regions }\end{array}$ & $\begin{array}{c}\text { Dnipropetrovska, Zaporizka, Lvivska, } \\
\text { Chernivetska, Chernihivska, Khersonska, } \\
\text { Kirovohradska, Vinnytska, Sumska, Cherkaska, } \\
\text { Zhytomyrska, Volynska, Poltavska, Rivnenska, } \\
\text { Ternopilska, Khmelnytska regions }\end{array}$ & $\begin{array}{c}\text { Ivano-Frankivska, Zakarpatska, } \\
\text { Luhanska, Donetska regions }{ }^{1}\end{array}$ \\
\hline
\end{tabular}

Data source [20]

Ukraine has been demonstrating an increasing polarization over the years of independence. Only in the last 10 years the Kyiv city's share in the gross regional product (GRP) in the overall structure has increased from $18.9 \%$ to $23.4 \%$. Accordingly, the per capita GRP in Kyiv exceeds more than 3 times the Ukrainian average, and 7.6 times the minimum (Fig. 1). The corresponding increase can be also seen in the Taylor index, when measuring the cross regional inequality of GRP distribution (0.06 in 2000, 0.19 in 2019). For most indicators the situation is similar. In addition, the correlation between the level of economic development (GRP, industrial production, international economic activity) and social and environmental indicators is quite weak, which can be illustrated using the example of several indices as well as analysis of population changes. The differentiation by the sustainable development

1 The current administrative centers of the territories controlled by Ukraine in the Luhanska and Donetska regions account for $\mathrm{r} 5 \%$ and $4 \%$ of the population respectively. Prior to the occupation, as of January 1,2014 , it was $18.9 \%$ and $21.9 \%$, respectively. 


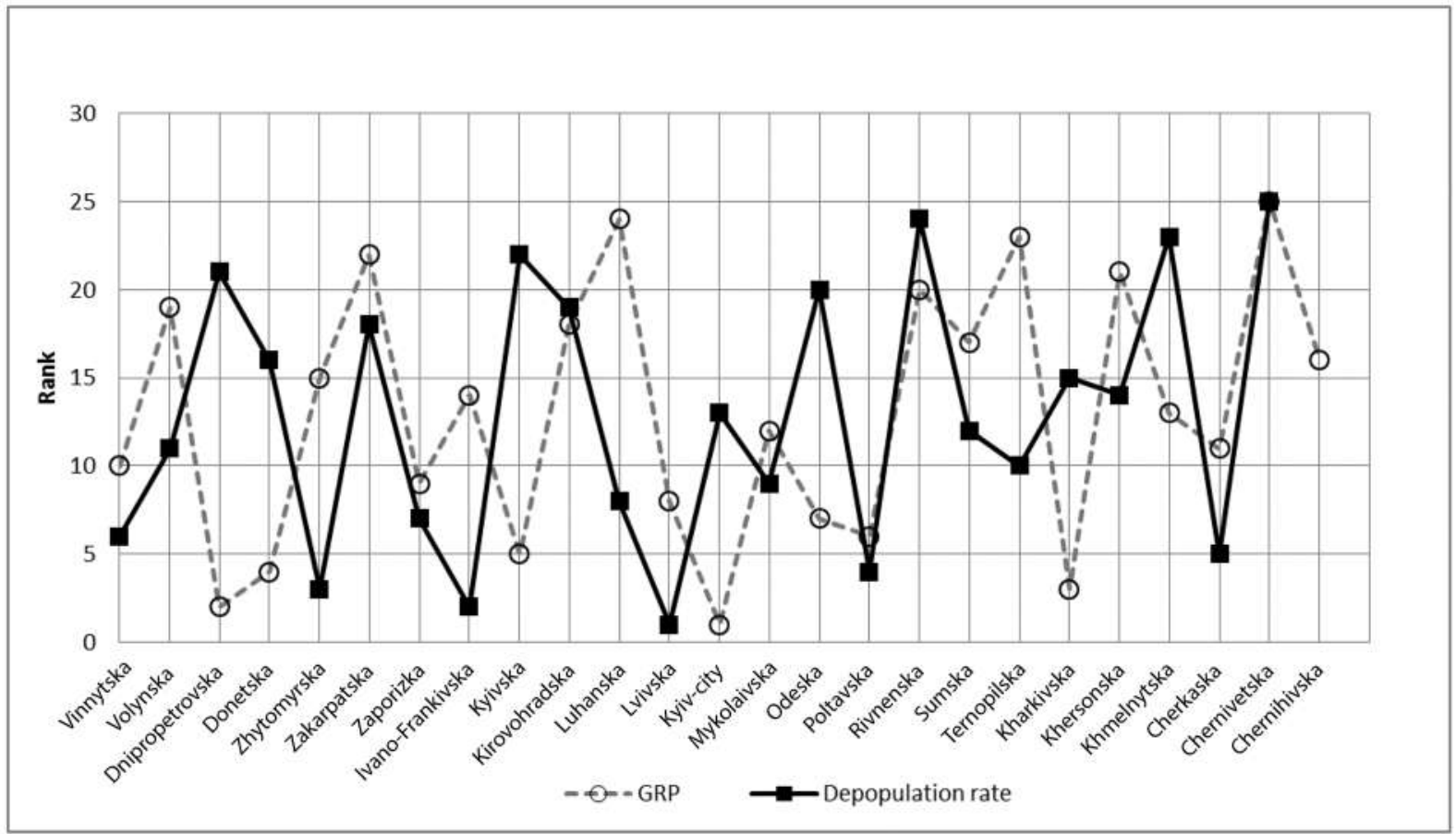

Fig. 2. GRP and depopulation in Ukrainian regions (oblast) ${ }^{2}$

index is even more pronounced [12].

Taking into account the well-known problems of the resource-oriented model of the economy, unacceptable from the point of view of postindustrial society, the current economic domination of 5-7 highly urbanized industrial regions is quite tentative advantage which needs to be re-evaluated in the process of further strategizing.

Changes in regional settlement systems deserve special attention. Apart from the obvious upward trend in Kyiv and, actually, in the Kyiv metropolitan area, similar processes can be also seen in other regions. Quite often it leads to the emergence of a fixed periphery, the decline of small towns and rural areas. The share of population of regional centers in the population of the region is presented in Table 1.

At the same time there is an ongoing process of population decline which is most pronounced in the eastern and central regions, where for the past 5 years (2014-2019) its average speed was 4\% [State Statistic Service]. The inverse correlation between the GRP value and the rate of population decline (Fig.2) often is an interesting phenomenon.

Out of 102 cities with population over 50,000 people as of 1989, 21 remained in the occupied territories of Donbass and annexed Crimea, and 10

\footnotetext{
${ }^{2}$ Rank 1 is the best value
}

ones moved to the below 50,000 category. In addition to cities in Donetska and Luhanska regions the reduction also affected the cities of Dnipropetrovska, Sumska and Kharkivska regions, while in some Western Ukrainian cities there was a small increase in population (Ivano-Frankivsk, Kovel, Lutsk, Novovolynsk, Rivne).

No less significant is the gap in the management of a certain types of territories or some special territories. Only in the draft Strategy for National Regional Development 2027 the priority "Focus on the solution of the complex projects considering peculiarities of the problem areas" is declared. Unfortunately, for a long time development challenges within mountainous and coastal regions have been neglected. Along with the mountainous and coastal territories some special measures are also needed for the old industrial regions, as well as for the capital region, for which the well-founded and approved Concept of Kyiv agglomeration, or the metropolitan region, becomes the main condition for further development and competitiveness on macroregional and global scale.

In situation when the "space of flows" successfully competes with the "space of places", the concept of networks becomes particularly important for regional policy. In Ukraine, the issue of being accessible and connected remains acute at all levels, from the 


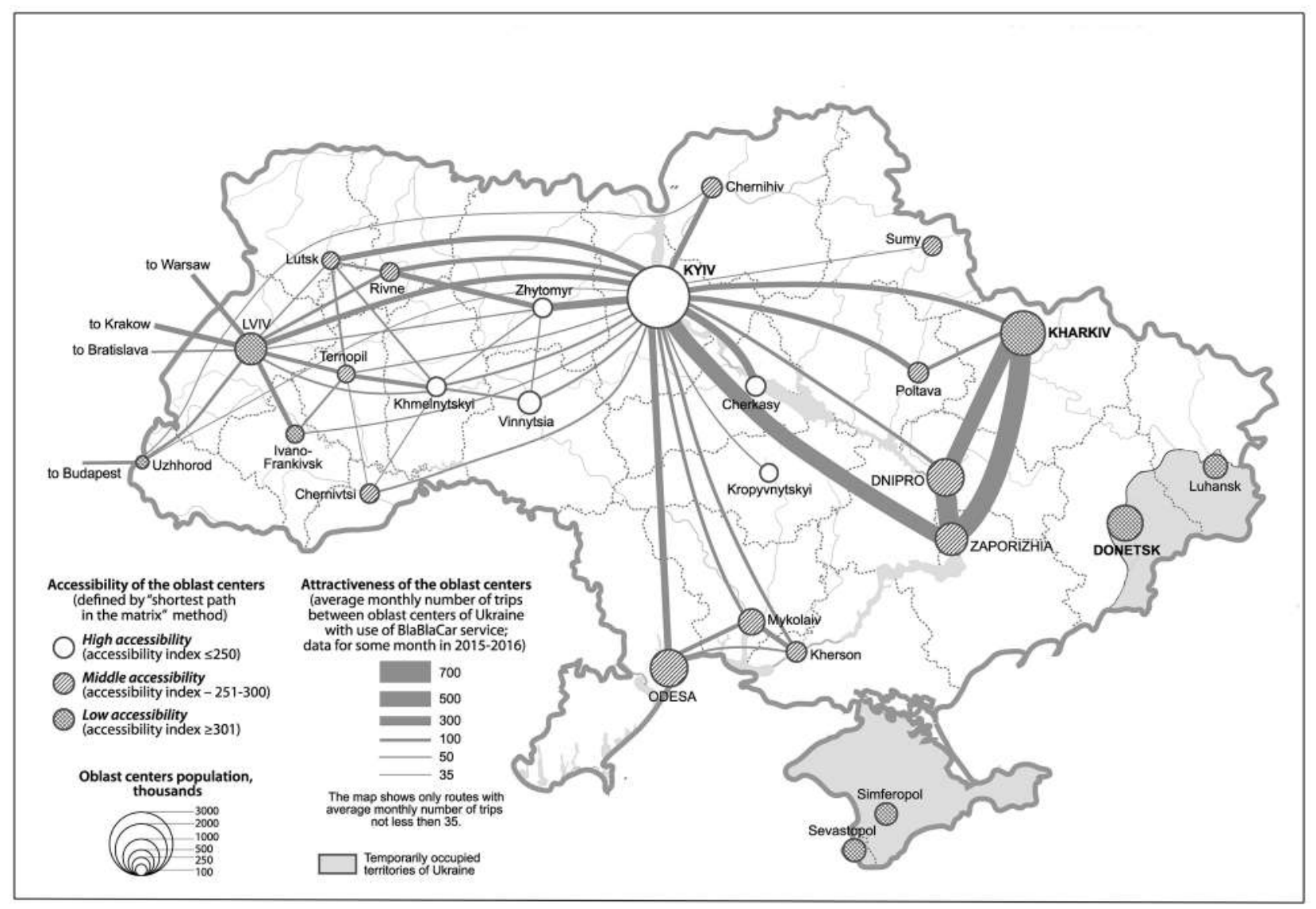

Fig. 3. Ukrainian regional centers: the accessibility and attractiveness. Source: [21]

countrywide to the local one, and it allows to speak of "localization discrimination" - hypertrophied distance expenses. Despite some noticeable changes inter-regional and intra-regional traffic is still limited by the convenience factors such as frequency or price and cause people to search for alternatives, particularly through the private transport. One of them is the Bla-bla-car service, the analysis of which allows to see the nature of demand by destination directions (Fig. 3).

Thus among the basic needs for the development of Ukrainian regions are dealing with the external challenges (geopolitical situation, globalization); polycentric approach as an axiom of spatial development, prudent financing and integrated planning; goals and action plan for the development of special/problem areas; reassessment of the regional economies internal potential (innovations, environmentally friendly development).

\section{Conclusions}

Being a part of the USSR for a long time, Ukraine inherited many stereotypes and models that impede regional and local development, create obstacles to the balanced country development. Simply destroying some of these patterns, without adequate replacement with modern management concepts, is rather a prerequisite for crisis than for potential growth and successful competition in a globalized world.

It is exactly this circumstance which has become one of the defining factors for the Ukraine state regional policy development during the years of independence. The formation of an appropriate institutional environment was going on with no clear geopolitical vector, high corruption risks, and unformed public consciousness. Scientists' recommendations, forecasts and concepts were almost not considered and followed by government structures in their actions. Support of international and European initiatives, transition of their practices and experience also has often remained declarative. The results are as follows:

- Imperfect regional development strategies and disintegration of sectoral policies. 
- Geopolitical challenges and occupation of part of the territory.

- The pronounced polarization of socioeconomic landscape, "resource-intensive" economic leadership.

- Lack of spatial framework concept and modern perspective of spatial development as a whole

- A number of unsettled ethno-cultural conflicts

- Fast degradation in peripheral and rural areas

- Challenges in urban territories development

- Insufficient development of transport networks and hubs.

Some conflicts caused by decentralization process have recently been added to this far incomplete list.

It is quite obvious that in order to solve these problems and react to some new challenges, an updated methodological base is needed, followed by significant changes in the institutional environment.

The principles of its regulation should become:

- Systematic, transparent and integrated nature of the policy

- The importance of the local level (bottom-up approach) and subsidiarity

- Partnership (involving all interested parties, especially the public)

- Significance of scientific and expert component

- Indicators and monitoring

- Environmentally friendly actions and intentions
- Combination of long-term and medium-term planning.

The methodological fundamentals will be set by the concepts of territorial capital (place-based approach), polycentric and balanced territorial development and territorial cohesion of the functional territories, as well as approaches to forecast and modeling of spatial development. Thematically, it is first of all balanced (sustainable) development, climate change, conservation of landscape and biological diversity, information society and innovations, globalization and competitiveness, urbanization, preservation of cultural values and all levels of security.

This must be the foundation where the development of a new State Regional Development Strategy, as well as a new General Planning Scheme for the territory of Ukraine should take place. The close thematic correlation of these documents, taking into account the goals set out in the sectoral strategic documents during their preparation, will allow to reach a new level in management of territories and to extend the necessary standards to regional and local levels. Measures aimed at organizing spatial data, ensuring their quality and accessibility within the national geospatial data infrastructure will also play an important role.

\section{References [Jimepamypa]:}

1. Pallot Judith (1981). Planning in the Soviet Union. University of Georgia Press in Athens, $303 \mathrm{p}$.

2. Alaiev E.B. (1977). Economic and geographical terminology. Moskow, 91 p. [In Russian].

[Е.Б. Алаев. Экономико-географическая терминология. Москва, 91 с.]

3. Morrill Richard L. (1974). The spatial organization of society. Duxbury Press, 267 p.

4. Poles of the socio-economic development of the territory: theoretical aspects of research (2014). Pidgrushnyi G.P. (ed). Problems of human geography. Iss. 3. Kyiv, 97 p. [In Ukrainian].

[Полюси соціально-економічного розвитку території: теоретичні аспекти дослідження / За наук. ред. Г.П. Підгрушного // Проблеми суспільної географії. 2014. Вип. 3. Матеріали теоретико-методологічного семінару, Інститут географії НАН України, 29 вересня 2013 р. Київ, 97 с.]

5. EU project 'Support for regional development policy in Ukraine'. Analytical report Regional development and state regional policy in Ukraine: the status and prospects of changes in the context of global challenges and european policy standarts. URL: https://surdp.eu/uploads/files/Analytical_Report_Main_part_UA.pdf [In Ukrainian].

[Регіональний розвиток та державна регіональна політика в Україні: стан і перспективи змін у контексті глобальних викликів та європейських стандартів політики. Аналітичний звіт. Проект ЄС “Підтримка політики регіонального розвитку в Україні URL:https://surdp.eu/uploads/files/Analytical_Report_Main_part_UA.pdf ]

6. Marynych A.M., Gorlenko I.A., Rudenko L.G. et al. (1990). Constructive-geographical bases of rational nature management in the Ukrainian SSR. Theoretical and methodological studies. (Editor-in-chief: A.M. Marinich, M.M. Palamarchuk). Kiev, 1990. 200 p.] Kyiv, 200 p. [In Russian].

[Маринич А.М., Горленко И.А., Руденко Л.Г. и др. Конструктивно-географические основы рационального природопользования в Украинской ССР. Теоретические и методологические исследования. (Отв. ред. А.М. Маринич, М.М. Паламарчук). Киев, 1990. 200 с.]

7. Kuybida V.S., Negoda V.A., Tolkovanov V.V. (2009). Regional Development and Spatial Planning of Territories: Experience of Ukraine and other Council of Europe member states. Kyiv, 176 p. [In Ukrainian]. 
[Куйбіда В.С., Негода В.А., Толкованов В.В. Регіональний розвиток та просторове планування територій: досвід України та інших держав членів Ради Свропи. Київ, 2009. 176 с.]

8. Baranovskyi M.O. (2007). Depressive territories: the essence of the concept, features of development, approaches to typology. Ukrainian geographical journal, 3, 26-30. [In Ukrainian].

[Барановський М.О. Депресивні території: сутність поняття, особливості розвитку, підходи до типології // Укр. геогр. журн. 2007. №3. С. 26-30.]

9. Carlin M.I. (2006). Problems and ways of depressed region development (a case of regions of Polissya economic district). Lutsk. 332 p. [In Ukrainian].

[Карлін М.І. Проблеми і шляхи розвитку депресивного регіону (на прикладі областей Поліського економічного району): Монографія. Луцьк, 2006. 332 с.]

10. Shevchuk Ya.V. (2004). Rehabilitation mechanisms of depressed territorial social systems in the context of regional policy-making. Lviv, 63 p. [In Ukrainian].

[Шевчук Я.В. Механізми санації депресивних територіальних суспільних систем в контексті формування регіональної політики. Льві,в 2004, 63 с.]

11. Gorlenko I.A., Rudenko L.G., Maliuk S.N., Balabanov G.V., Lebed N.P. (1994). Issuess of complex development of the territory. Kyiv, 296 p. [In Russian].

[Проблемы комплексного развития территории / Горленко И.А., Руденко Л.Г., Малюк С.Н., Балабанов Г.В., Лебедь Н.Р. Киев, 1994. 296 с.]

12. Lisovskyi S.A. (2009). Society and Nature: Balance of Interests in Ukraine. Kyiv, 300 p. [In Ukrainian]. [Лісовський С.А Суспільство і природа: баланс інтересів на теренах України. Київ, 2009. 300 с. ]

13. Rudenko L.H., Gorlenko I.O., Gukalova I.V. et al. (2004). Assessment of the implementation status of the final documents of the World Summit on Sustainable Development (Johannesburg, 2002) in Ukraine. Kyiv, 208 p. [In Ukrainian].

[Оцінка стану виконання підсумкових документів Всесвітнього саміту зі сталого розвитку (Йоганнесбург, 2002) в Україні / Л. Г. Руденко, І. О. Горленко, І. В. Гукалова та ін. Київ, 2004. 208 с.]

14. Status of implementation of the Agenda 21 in Ukraine (2002 - 2012). (2014). L.G. Rudenko (ed.). Kyiv, 359 p. [In Ukrainian].

[Стан виконання в Україні положень «Порядку денного на XXI століття» (2002 - 2012) / За ред. Руденко Л.Г. Київ, 2014. 359 с.]

15. Sustainable Development Strategy of Ukraine until 2030 (draft). (2017). UNDP, Kyiv. URL: https://www.undp.org/ content/dam/ukraine/docs/SDGreports/UNDP_Strategy_v06-optimized.pdf [In Ukrainian].

[Стратегія сталого розвитку України до 2030 року (проект) Київ, 2017, ПРОOH URL: https://www.undp.org/ content/dam/ukraine/docs/SDGreports/UNDP_Strategy_v06-optimized.pdf ]

16. Rudenko L. H., Lisovskyi S.A., Maruniak Eu.O. (2016). Environmental guidline in priorities of integral planning process in Ukraine. Ukrainian geographical journal, 4, 9-16. DOI: https://doi.org/10.15407/ugz2016.04.009 [In Ukrainian].

[Руденко Л.Г., Лісовський С.А., Маруняк Є.О. Екологічний імператив у пріоритетах інтегрованого планувального процесу в Україні// Укр. геогр. журн. 2016. №4, С. 9-16. DOI: https://doi.org/10.15407/ugz2016.04.009]

17. Sabine von Löwis (2019). Socio-spatial differences and representations of the past and its reflection in Western Ukraine. Ukrainian geographical journal, 1, 59-68. DOI: https://doi.org/10.15407/ugz2019.01.059 [In Ukrainian]. [Сабіна фон Льовіс. Соціально-просторова диференціація минулого України та ії прояв у Західній Україні // Укр. геогр. журн. 2019. №1. C.59-68. DOI: https://doi.org/10.15407/ugz2019.01.059]

18. Lefebvre H.(2006). Die Produktion des Raums. Raumtheorie: Grundlagentexte aus Philosophieund Kulturwissenschaften. Frankfurt am Main, p. 330-342.

19. Maruniak Eu.O. (2020). Spatial development of Ukraine in global vision. Herald of the National Academy of Sciences of Ukraine, 4. 73-83. DOI: https://doi.org/10.15407/visn2020.04.073 [In Ukrainian].

[Маруняк Є.О. Просторовий розвиток України у глобальній візії // Вісник національної академії наук України. 2020. № 4. C. 73 - 83. DOI: https://doi.org/10.15407/visn2020.04.073]

20. State Statistic Service of Ukraine. URL: http://www.ukrstat.gov.ua/ [In Ukrainian]. [Державна служба статистики України. URL: http://www.ukrstat.gov.ua/]

21. Maruniak Eu.O. (2018). Geospatial research and planning practice: Ukraine within global trends. Kyiv, 336 p. [In Ukrainian].

[Маруняк Є.О. Геопросторові дослідження і практика планування: Україна на тлі світових трендів. Київ, 2018. $336 \mathrm{c.}$ ]

The paper received 5.07.2020 